\title{
The Effect of Remittances on Economic Growth in Ethiopia: A Time Series Analysis (1980/81-2017/18)
}

\author{
Melkamu Wondimu Habtamu Solomon \\ Lecturer, Department of Economics, Mizan- Tepi University, Ethiopia
}

\begin{abstract}
For more than half a century, regardless of its increasing importance, the effect of remittances on economic growth has not adequately studied. In this study the empirical relationship between economic growth and remittances was investigated by using an ARDL bound approach to cointegration in Ethiopia during the period 1980/81-2017/18. According to the findings of this paper the estimated coefficients of the level of remittance inflows were found to influence the economic growth positively and significantly both in the long run and short run. Moreover in order to confirm the relationship and the impact of remittances inflows on economic growth co-integration and causality tests were conducted on the macroeconomic variables data collected. The outcome of co-integration test showed that there is a long-run equilibrium relationship between real GDP, remittance inflows, human capital, labor force, rate of inflation, gross capital formation and national saving. The result of causality test also shows that there is a unidirectional causality running from remittance inflows to GDP.
\end{abstract}

Keywords: Remittances, Economic growth, ARDL

DOI: $10.7176 / \mathrm{EJBM} / 12-1-02$

Publication date: January $31^{\text {st }} 2020$

\section{INTRODUCTION}

In the global economy, remittances represent one of the major international flows of financial resources. The category workers' remittances in the balance of payments best represents what economists have in mind when modeling remittances. It represent one of the most important mechanisms for the transfer of resources from developed to developing countries, and remittances are the second-largest source, next to foreign direct investment as external assistance for developing countries. Remittances can lead to reduced country risk and government debt. In addition to increasing household savings, significant remittances inflows can directly or indirectly increase the revenue base; thereby reduce the marginal cost of raising revenue. Remittances may reduce the government incentive to maintain fiscal policy discipline. They are not necessarily associated with an increase on domestic investments or a more efficient allocation of domestic investments (Shera and Meyer 2013). The amount of global remittance is about $\$ 573.6$ billion in 2016 and Remittance inflows to Sub-Saharan Africa grew from $\$ 34$ billion in 2016 to $\$ 38$ billion in 2017.This increase is partly backed by a pickup in global economic growth, especially in the high-income OECD countries. Also, a rebound in oil prices since July 2017 boosted economic activities in oilproducing countries. Both OECD and oil-producing countries host many Sub-Saharan African migrants (KNOMAD 2017).

Remittances are an extremely important source of foreign exchange for Ethiopia. Based on the NBE figures which puts remittances at USD 3.7 billion in 2015, the International Monetary Fund (IMF) figures place the total value of remittances to Ethiopia at USD 3-3.5 billion (2014/2015) or 7.4 per cent of GDP. However, official figures from the World Bank are far lower, placing the total received in 2014/15 at USD 624 million, which would make only 0.29 per cent of GDP. The NBE record of cash transfers from private individuals are estimated at USD 2.7 billion in 2014/2015, which is almost four times the World Bank estimate. The disparity in figures recorded is due to the inclusion of underground private transfers in the data of NBE (Isaacs 2017).

Ever since the early start of the economic reforms in Ethiopia many researchers have tried to access the effects of remittances on economic growth and come up with different results. But some of them failed to include variablees like national saving which is powerful in the analysis of growth and remittance relationship. Most of these researches have both knowledge and methodology gaps. So this paper tries to fill this gap and extend the literature of growth remittance relationship up to the year 2018 .

\subsection{Objectives of the Study}

\subsubsection{General objectives}

The ultimate objective of the study is to examine the effect of remittances on economic growth.

1.3.2 Specific objectives

The specific objectives of the study include the following

$>$ To assess whether remittances significantly affect economic growth or not

$>$ To analyze the trend of economic growth with respect to remittances

$>$ To examine the causal relationship between remittances and economic growth 


\section{Literature Review}

\subsection{Definition and concepts of economic growth}

Economic growth can be defined as a positive change in the level of goods and services produced by a country over a certain period of time. An important characteristic of economic growth is that it is never uniform or same in all sectors of an economy For example, in a particular year; the telecommunication sector of a country has marked a significant contribution in economic growth whereas the mining sector has not performed well as far as the economic growth of the country- is concerned. Economic growth is measured by an increase in the increase in the country's total output or real Gross Domestic Product (GDP) or Gross National Product (GNP). The Gross Domestic Product of a country is the total value of all final goods and services produced within a country over a period of time (Pettinger 2017).

\subsection{Definition and concepts of Remittances}

A remittance can be defined as the cross border transfer of funds from one party to another party. Remittances can be sent to another country through different mechanisms like a wire transfer, mail, draft, or check. Remittances can be used to cover any type of payments such as an invoice, but it's typically used to pay or assist family members back in a person's home country (Kagan and Murphy 2019).

According to the new definition, given by IMF personal remittances is the sum of two main components compensation "Compensation of employees" and "personal transfers. Personal remittances also consist of a third item: "capital transfers between households, and Compensation of employees, which "represents remuneration in return for the labor input to the production process contributed by an individual in an employer-employee relationship with the enterprise." The definition of "personal transfers," however, is broader than the old "workers' remittances" it comprises "all current transfers in cash or in kind made or received by resident households to or from nonresident households." Therefore, "personal transfers" includes current transfers from migrants not remittance outflows, although the countries are important destinations for migrants (KNOMAD, 2017).

\subsection{Theories of Remittance}

In spite of the important role played by migrants' remittances, no systematic theory of remittance behavior exists and surprisingly little statistical evidence on determinants of remittances has appeared. This theoretical aspect of the literature presents several hypotheses for motivations to remit, ranging from pure altruism to self-interest and then proceeds to a model of tempered altruism or enlightened self-interest in which remittances are one element in a self-enforcing arrangement between migrant and home (Lucas and Stark 1985).

\section{A) Pure Altruism}

Pure altruism is a theory of remittance which relies on the derived utility of the migrant from transferring resources to those who left at home; which is assumed to depend on per capita consumption. The altruistic model advances a number of hypotheses. First, the altruistic transfer increases with the migrant's income and degree of altruism. Second, the amount of remittances decreases with an increase in the recipient's income and, third, remittances should decrease over time as the attachment to the family gradually weakens. The same should happen when the migrant settles permanently in the host country and family members follow. Empirical evidence from Botswana gave support to the first prediction. A $1 \%$ increase in the migrant's wage, ceteris paribus, induced increases in remittances ranging from $0.25 \%$, at low wage levels, to $0.73 \%$, at high wage levels. However the correlation between remittance levels and home incomes was found to be insignificant. Thus, altruism was found to be insufficient for explaining the motivations to remit, at least for Botswana (Lucas and Stark 1985).

\section{B) Pure Self-Interest}

A theory of pure self interest basically identifies three motives to remit. The first is the aspiration to inherit. Assuming that inheritance is habituated in behavior, an acquisitive migrant's motives for supporting his or her family, and particularly parents, may cover the concern to maintain favor in the line of inheritance. If this is appropriate, the larger is the degree of remittance, the larger would be the potential inheritance. A second selfinterest of the migrant in remitting home may be to invest in assets in the home area and ensure their careful maintenance. In this context, one's own family may be a particularly trustworthy agent both in selecting the specific item for purchase (land, cattle, etc.) and in maintaining the asset on the migrant's behalf Such motivations are generally the sign of a temporary migration, and signal the migrants' intention to return. Another intuitive way to think of such type of investment in fixed asset is through initiation of market exchange which reduces market imperfections and saved transaction on through non-market interpersonal agreements. For example, migrants' remittances may be viewed as repayments of loans used to finance the migrant's investments in human capital or the expenditures incurred in the course of migration (Rapoport and Docquier 2004). Third is the intent to return home, which may suffice to promote remittance for investment in fixed capital such as land, livestock, or a house, in public assets to enhance prestige or political influence, and in what might be termed social assets-the relationships with family and friends (Lucas and Stark 1985). 


\section{c) Tempered Altruism or Enlightened Self-Interest}

The tempered altruism theory views remittances as part of an inter-temporal, mutually beneficial contractual arrangement between the migrants and their family. The underlying idea is that for the household as a whole it may be a Pareto-optimal strategy to have members migrate elsewhere, either as a means of risk sharing or as an investment in access to higher earnings streams. Remittances may then be seen as a device for redistributing gains, with relative shares determined in an implicit arrangement struck between the migrant and remaining family. The migrant adheres to the contractual arrangement so long as it is in his or her interest to do so. This interest may be either altruistic or more self-seeking, such as concern for inheritance or the right to return home ultimately in dignity. Remitting may thus cease either if the arrangement is no longer self-enforcing or if the contractual terms themselves provide for cessation of transfers at a given point in time (Lucas and Stark 1985).

\section{Research Methodology}

\subsection{Data Type and Data Source}

In order to undertake the study the researcher has relied on secondary data sets which were collected from different sources. The data for real GDP per capital, labor force, gross capital formation, rate of inflation, and domestic saving rate was collected from National Bank of Ethiopia, whereas the data human capital and remittance inflows was obtained from World Development Indicators data base.

\subsection{Specification of the Model \\ The Long Run ARDL Model}

To examine the existence of the long run relationship between the variables the following version of ARDL model is used.

$\operatorname{lnRGDP}_{\mathrm{t}=} \alpha_{0}+\sum_{i=1}^{n} \alpha_{1} \operatorname{lnRGDPt}_{-1}+\sum_{i=1}^{k} \alpha_{2} \mathrm{LNHC}_{\mathrm{t}-1}+\sum_{i=1}^{k} \alpha_{3} \operatorname{lnREM} \mathrm{ln}_{\mathrm{t}-1}+\sum_{i=1}^{k} \alpha_{4} \operatorname{lnLF}_{\mathrm{t}-1}+\sum_{i=1}^{k} \alpha_{5} \operatorname{lnGCF}_{\mathrm{t}-1}+$

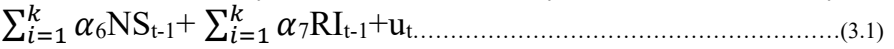

Where; RGDP=Real GDP per capital, HC=Human Capital, REM=Remittance inflows, LF=Labor Force, GCF= Gross Capital Formation, NS=National Saving, RI= Rate of Inflation, $\alpha$ represents parameters to be estimated, ln represents natural logarithm, $t$ is the time period considered for the study, and $U$ represents the error term.

\subsection{Data Analysis}

Once the data was collected and the model is clearly specified the next step is to analyze the data. In order to analyze the data systematically the researcher has used Eviews 9 software. The reason for the selection of this software was the flexibility and comfortableness for tabulation, graphing and data generating process.

\subsection{Estimation Strategy}

In order to estimate the model the researcher has followed six steps i) the test of stationarity of the individual series in the regression model is undertaken to determine the order of integration of the variables, ii) the ARDL bound Test of Cointegration is undertaken to establish existence of a stable long-run equilibrium relationship among the variables in the model and iii) the estimation of the parameters of the model in equation 3.1, iv) diagnostic tests were undertaken to ensure that there is no problem in the residuals from the estimation of a model, v) Granger Causality Tests were undertaken to know the direction of causality, and Vi ) Stability tests were undertaken to know whether the parameters in the model are Stability or not.

\section{Data Analyses and Discussion of Empirical Results}

\subsection{Results for Unit Root Test}

One of the most important steps for applying an ARDL model was to perform stationarity test. This is a test which helps to avoid the crashing of ARDL model application as a result of the non-stationarity of the data. It enables to identify the order of integrated level of the variables, so that there will be no spurious regression. The results from ADF test can be discussed below. 
Table 4.1 ADF test for unit root

\begin{tabular}{|c|c|c|c|c|c|c|}
\hline \multirow[t]{2}{*}{ Variables } & \multicolumn{3}{|c|}{ ADF t-statistic at level I(0) } & \multicolumn{2}{|c|}{$\begin{array}{l}\text { ADF t-statistic at first } \\
\text { difference I(1) }\end{array}$} & \multirow{2}{*}{ 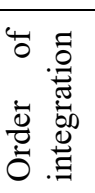 } \\
\hline & Intercept & $\begin{array}{l}\text { Intercept and } \\
\text { trend }\end{array}$ & None & Intercept & $\begin{array}{l}\text { Intercept and } \\
\text { trend }\end{array}$ & \\
\hline $\operatorname{lnRGDP}$ & $4.207608 *$ & 0.057389 & $3.788545^{*}$ & $-5.121884 *$ & $-6.370497 *$ & $\mathrm{I}(0)$ \\
\hline $\ln \mathrm{HC}$ & -0.685174 & -2.222183 & $2.997631 *$ & $-8.165791 *$ & $-8.047179 *$ & $\mathrm{I}(1)$ \\
\hline $\ln R E M$ & -0.650959 & -2.449614 & 1.092701 & $-5.957442 *$ & $-5.846898 *$ & $\mathrm{I}(1)$ \\
\hline $\operatorname{lnLF}$ & 0.694354 & -0.956826 & $2.850490 *$ & $-4.150970 *$ & $-4.120195 *$ & $\mathrm{I}(1)$ \\
\hline RI & $-4.676961 *$ & $-4.933279 *$ & -1.278886 & $-8.452430 *$ & $-8.323669 *$ & $\mathrm{I}(0)$ \\
\hline NS & $5.648465 *$ & $4.093293 * *$ & $3.625562 *$ & 2.190897 & $-6.236813 *$ & $\mathrm{I}(0)$ \\
\hline $\operatorname{lnGCF}$ & 0.938211 & -1.515824 & $2.494307 *$ & $-7.123495 *$ & $-7.805381 *$ & $\mathrm{I}(1)$ \\
\hline
\end{tabular}

Mackinnon (1996) Critical Values

$\begin{array}{lcrcc}\text { Critical Values } & \text { Intercept } & \text { Intercept \& trend } & \text { None } & \text { Significance } \\ 1 \% & -3.632900 & -4.226815 & -2.628961 & * \\ 5 \% & -2.948404 & -3.536601 & -1.950117 & * * \\ 10 \% & -2.612874 & -3.200320 & -1.611339 & * * *\end{array}$

Source: Own computation

Note: $* * *, * * *$ shows that the variables are significant at $1 \%, 5 \%$ and $10 \%$ respectively.

As it was shown table 4.2 variables like $\operatorname{lnHC}, \operatorname{lnREM}, \operatorname{lnLF}$ and $\operatorname{lnGCF}$ are non-stationary at level and become stationary after taking first difference. This implies that these three series are integrated of order one, i.e. I (1), while lnRGDP, RI, and NS are stationary at level, i.e. I (0). In general as it was shown in the table, since the order of integration of all the variables is not same, the mixed results obtained from the unit root test justify using ARDL technique to estimate the long-run and short-run relationship among the variables under investigation.

\subsection{Results for Bound Test of Cointegration}

One of the major ways to test for cointegration and causality in ARDL modeling approach is the Bound Test for Cointegration. This model was developed by Pesaran et al. (2001) and can be applied irrespective of the order of integration of the variables (irrespective of whether regressors are purely $I(0), I(1)$ or mutually cointegrated).

Table 4.2 ARDL Bound Approach to Cointegration

\begin{tabular}{|l|l|l|l|l|l|l|}
\hline \multirow{3}{*}{ Test statistic } & \multirow{2}{*}{ value } & \multicolumn{4}{|c|}{ Critical Value Bounds } \\
\cline { 3 - 7 } & & $\begin{array}{l}\text { Based on Pasaran et.al } \\
\text { values of 2001 }\end{array}$ & $\begin{array}{l}\text { Based on Narayan } \\
\text { values }\end{array}$ \\
\cline { 3 - 7 } & & $\begin{array}{l}\text { level of Statistical } \\
\text { significance }\end{array}$ & $\mathrm{I}(0)$ & $\mathrm{I}(1)$ & $\mathrm{I}(0)$ & $\mathrm{I}(1)$ \\
\hline F- statistic & 8.022690 & $1 \%$ & 2.88 & 3.99 & 3.68 & 5.14 \\
\cline { 3 - 7 } & $5 \%$ & 2.27 & 3.28 & 2.66 & 3.89 \\
\cline { 3 - 7 } & $10 \%$ & 1.99 & 2.94 & 2.23 & 3.35 \\
\hline
\end{tabular}

Source: Own computation

As it was shown in table 4.2 Since the results from Pasarian F- statistic critical values of 8.022690 are greater than the Pasarian upper bound critical values at $1 \%$ the null hypothesis of no cointegration has been rejected and the existence of the long run relationship between the variables has been assured. In addition to the Pasaran critical value tables, since the Narayan critical value are less than the F-statistic critical values the existence of long run relationship between the variables is further ensured.

\subsection{Estimation Results of the Long run ARDL model}

Once the existence of the long run relationship between the variables is identified the next step in ARDL model is to estimate the long run coefficients. The regression results for the ARDL model $(2,3,3,3,0,2,3)$ selected by Akaike Information Criteria (AIC) can be given in table 4.3.

The long run ARDL model equation can be written as follows

$\mathrm{LNRGDP}=3.6366+0.1095 \mathrm{LNREM}+4.9415 \mathrm{e}^{-07} \mathrm{NS}+0.2252 \mathrm{LNGCF}+0.2103 \mathrm{LNHC}+0.3732 \mathrm{LNLF}-0.0021$

RI 
Table 4.3 Coefficients of the Long Run Model

\begin{tabular}{|l|l|l|l|}
\hline Variables & Coefficient & Std. Error & T-Ratio [Prob] \\
\hline LnHC & 0.210294 & 0.044380 & $4.738467\left[0.0005^{*}\right]$ \\
\hline LnREM & 0.109487 & 0.023849 & $4.590763\left[0.0006^{*}\right]$ \\
\hline LnLF & 0.373178 & 0.059870 & $6.233185\left[0.0000^{*}\right]$ \\
\hline NI & -0.002051 & 0.002284 & $-0.897638[0.3870]$ \\
\hline LnGCF & $4.9415 \mathrm{e}^{-07}$ & $5.1389 \mathrm{e}^{-07}$ & $0.961574[0.3552]$ \\
\hline C & 0.225248 & 0.081859 & $2.751669\left[0.0175^{*}\right]$ \\
\hline & 3.636592 & 0.278278 & $13.068179\left[0.0000^{*}\right]$ \\
R-squared & 0.999829 & Mean dependent var & 12.43876 \\
Adjusted R-squared & 0.999515 & S.D. dependent var & 0.785695 \\
S.E. of regression & 0.017296 & Akaike info criterion & -5.032810 \\
Sum squared resid & 0.003590 & Schwarz criterion & -4.010725 \\
Log likelihood & 111.0742 & Hannan-Quinn criter. & -4.679987 \\
F-statistic & 3188.496 & Durbin-Watson stat & 1.924218 \\
Prob(F-statistic) & 0.000000 & \\
\hline
\end{tabular}

Source: Own computation

Note: ${ }^{*}, *$ shows that the probability values of the coefficients in the parentheses are significant at 1 percent and 5 percent respectively.

As it was shown in table 4.3 the R-squared of the model tells us that $99 \%$ of the variation in real GDP is explained by all the independent variables included in the model. Since the F-statistic probability is very significant the model is nicely fitted.

In this study as it was expected and as theoretically stated by many scholars human capital measured by secondary school enrollment is found to have positive and statistically significant impact on economic growth measured by real GDP. Other things remaining constant a one percent increase in human capital will result in an increase in economic growth by 21 percent.

The level of remittance inflows, which is the main variable for this study, is found to have a positive and statistically significant impact on growth. Holding other things constant when the remittance inflow measured as a percentage share of GDP increases by one percent economic growth is likely to increase by 10 percent.

Like human capital and remittance inflows labor force is also found influencing economic growth positively and significantly. Due to the reason that Ethiopian economy is agrarian in nature and the majority of the population is employed in rural area it is likely that labor force participation influence output by increasing agricultural productivity. A one percent increase in labor force participation will increase the output growth by 37 percent.

Another most important variable which is expected to explain economic growth and employed in this model was the gross capital formation (investment). As it was theorized by Neo Classical economists an increase in investment will result in an increase in output and the growth in output will result in further investment. In this study when gross capital formation increases by one percent, economic growth increases by 22 percent holding other things constant.

\subsection{Estimation Results of the Short Run and Error Correction Model}

After the long run model is clearly specified and the effect of the regressors on the regressand is clearly interpreted what comes next is the estimation of the short run coefficients along with the short run Error Correction Term (ECT). Thus the ECT shows the short run dynamics of the model beside with the long run adjustment.

In theory the lagged values of ECT has to be negative and statistically significant so that it is good to have an adjustment towards the long run equilibrium. As it was shown in table 4.4 the lagged values of the ECT is negative and statistically significant. The size of the error correction term in this model is about -0.828653 and this shows that about $82 \%$ of the deviation from the long run equilibrium is corrected during each year.

When we compare the results of the long run and the short run coefficients except for national saving (NS), labor force (lnLF) and gross capital formation (lnGCF) the results for the other variables are consistent with the long run estimates. 
Table 4.4 Estimates of the short run and Error Correction Term (ECT)

\begin{tabular}{|c|c|c|c|}
\hline Variable & Coefficient & Std. Error & T-Ratio [Prob.] \\
\hline D(LNRGDP(-1)) & 0.273832 & 0.108613 & $2.521165\left[0.0269^{* *}\right]$ \\
\hline D(LNREM) & 0.036469 & 0.011728 & $3.109605[0.0090 *]$ \\
\hline D(LNREM(-1)) & -0.004221 & 0.013315 & $-0.317016[0.7567]$ \\
\hline D(LNREM(-2)) & -0.052009 & 0.013505 & $-3.851057[0.0023 *]$ \\
\hline $\mathrm{D}(\mathrm{NS})$ & $2.3136 \mathrm{e}^{-06}$ & $1.4231 \mathrm{e}^{-07}$ & $16.257561\left[0.0000^{*}\right]$ \\
\hline $\mathrm{D}(\mathrm{NS}(-1))$ & $-4.1050 \mathrm{e}^{-07}$ & $3.0221 \mathrm{e}^{-07}$ & $-1.358316[0.1994]$ \\
\hline $\mathrm{D}(\mathrm{NS}(-2))$ & $1.4162 \mathrm{e}^{-06}$ & $4.9550 \mathrm{e}^{-07}$ & $2.858087\left[0.0144^{* *}\right]$ \\
\hline $\mathrm{D}$ (LNGCF) & 0.055156 & 0.028953 & $1.905027 \quad[0.0810]$ \\
\hline $\mathrm{D}(\mathrm{LNGCF}(-1))$ & -0.020544 & 0.038415 & $-0.534804[0.6026]$ \\
\hline $\mathrm{D}(\mathrm{LNGCF}(-2))$ & -0.094878 & 0.034737 & $-2.731307[0.0182 * *]$ \\
\hline $\mathrm{D}(\mathrm{LNHC})$ & 0.174261 & 0.036117 & $4.824859[0.0004 *]$ \\
\hline $\mathrm{D}$ (LNLF) & -0.145647 & 0.102720 & $-1.417910[0.1817]$ \\
\hline $\mathrm{D}(\mathrm{LNLF}(-1))$ & -0.683666 & 0.142889 & $-4.784611[0.0004 *]$ \\
\hline $\mathrm{D}(\mathrm{RI})$ & -0.000825 & 0.000650 & $-1.270096[0.2281]$ \\
\hline $\mathrm{D}(\mathrm{RI}(-1))$ & 0.000887 & 0.000656 & $1.353240[0.2009]$ \\
\hline $\mathrm{D}(\mathrm{RI}(-2))$ & 0.000807 & 0.000561 & $1.438114[0.1760]$ \\
\hline $\mathrm{ECT}(-1)$ & -0.828653 & 0.087208 & $-9.502001\left[0.0000^{*}\right]$ \\
\hline
\end{tabular}

Source: Own computation

Note: *,** shows that the probability values of the coefficients in the parentheses are significant at 1 percent and 5 percent respectively.

Like the long run model in the short run remittances are also found to have both positive and statistically significant impact on growth. A one percent increase in remittances can lead to an increase in economic growth by 3.6 percent.

In the short run model, like the long run human capital is also found to have a positive and significant impact on output growth. This is due to the fact that the more the people acquire education, the more they become experienced and the more there experience increases the more their productive capacity will be. Other things remaining constant the short run coefficient for human capital tells us that when school enrollment increases by one percent economic growth increases by 17 percent.

In the short run saving is found to have a positive and statistically significant impact on real GDP. A one percent increase in the domestic saving rate would account for 0.0002 percent increase in the growth rate of an economy. The major reason why saving becomes unexpectedly insignificant in the long run in our model is for the reason that the country has no sufficient high rate of domestic saving, it would need the external saving which makes it exposed to the uncontrollable risk from the world economic crisis. Low saving rates have generated a severe current account deficit in country by creating the saving investment gap. As a result internal saving could not meet the demand for investment, so the government has to borrow money to absorb the scarcity of internal saving. As the dependence on external saving increases, the risk exposure from currency and economic fluctuation also increases. At that time, the country will continually lose a lot of capital reserve and eventually failed to maintain the financial stability in the long run (Rasmidatta 2011).

The other variable for which the estimated short run result differs from the long run result is the gross capital formation (lnGCF). This variable becomes insignificant and its lagged value which is $\mathrm{d}(\operatorname{lnGCF}(-2))$ becomes negative and significant in the short run. The insignificance of the gross capital formation in the short run was because of the reason that it depends on saving which plays an important role in economic growth, allowing for more capital to be available for future production, so that the rate of economic growth can rise. But the existence of low level of domestic saving rate and the level of economic activity will result in volatility of investment causing it to fluctuate in the short run (Rittenberg 2012).

When we see the short run estimated coefficients of the labor force (lnLF), the lagged value of this variable, which is $\mathrm{d}(\operatorname{lnLF}(-1))$ becomes negative and statistically significant at five percentage. According to its lagged value estimates, when labor force increases by one percent the growth rate of an economy decreases by 68 percent. This negative result in the short run is because of the reason that at the early stage; the economy consists of the majority of the young population which is characterized by more dependence and less productivity.

\subsection{Model Diagnostic Tests}

Once the long run and the short run coefficients are estimated the next most important step in any model is to undertake the model diagnostic tests on the estimates of the residual of the ECM model. Diagnostic checks are crucial in this analysis, because if there is a problem in the residuals from the estimation of a model, it is an indication that the model is not efficient, such that parameter estimates from such model may be biased. Results 
from various tests such as the Jarque- Bera normality test, Breusch Pagan Godfrey serial correlation LM test, the Breusch Pagan Godfrey heteroskedasticity and autoregressive conditional heteroskedasticity (ARCH) tests undertaken in this study are presented in table 4.5

Table 4.5 Diagnostic Tests

\begin{tabular}{|l|l|l|}
\hline Types of tests & LM -Version & F -Version \\
\hline Serial Correlation & CHSQ $(2)=5.222774[0.0734]$ & $\mathrm{F}(2,10)=0.876974[0.4457]$ \\
\hline Normality & $0.992708[0.608746]$ & Not applicable \\
\hline Hetroscedasticity (BPG) & $\mathrm{CHSQ}(22)=22.58999[0.4252]$ & $\mathrm{F}(22,12)=0.992893[0.5255]$ \\
\hline Hetroscedasticity (ARCH) & $\mathrm{CHSQ}(1)=1.289468[0.2561]$ & $\mathrm{F}(1,32)=1.261459[0.2697]$ \\
\hline Ramsey RESET test & $\mathrm{df}(11)=1.174659[0.2649]$ & $\mathrm{df}(1,11)=1.379823[0.2649]$ \\
\hline
\end{tabular}

Source: Own computation

The results show that the residual from the error correction model is normally distributed because the P-value of the series, which are represented in our case as figures in parentheses, was insignificant. The null hypothesis of no serial correlation as confirmed by Serial Correlation LM Test cannot be rejected since the test statistics are also not significant. The test also confirms the absence of heteroskedasticity using both the Breusch Pagan-Godfrey (BPG) heteroskedasticity and ARCH tests. The Ramsey RESET test also indicates that there is no specification error in the model, hence indicating that the model is well behaved.

\subsection{Granger causality test}

A Granger Causality test is a test which enables us to identify the direction of the causality from where the lagged values of one variable in the past or present causes the future and; where the present and the future value responds to the cause in the past.

\section{Table 4.6 Results for Granger Causality Test}

\begin{tabular}{|l|l|l|l|}
\hline Null Hypothesis: & Obs & F-statistic & Prob. \\
\hline LNREM does not Granger Cause LNRGDP & 35 & 4.18168 & 0.0247 \\
\hline LNRGDP does not Granger Cause LNREM & & 0.55247 & 0.5811 \\
\hline
\end{tabular}

\section{Source: Own Computation}

Since the associated probability value of 0.0247 is less than $5 \%$ we reject the null hypothesis of LNREM does not Granger Cause LNRGDP and we can definitely conclude that there exists a uni-directional causality running from remittances to economic growth. On the other hand since the probability value for the null hypothesis of LNRGDP does not Granger Cause LNREM is greater than 5\% we fail to reject the null hypothesis and conclude that there is no causality running from LNRGDP to LNREM.

To sum up the results from the causality test of the model for the period under investigation shows that an increased inflow of remittance services can lead to an increase in economic growth of Ethiopia, while the increase in economic growth cannot lead to an increase in remittance inflows at the same time

\subsection{Stability Test}

In addition to the diagnostic tests, in order to guarantee the goodness of the model; we used cumulative sum (CUSUM) and CUSUM of squares tests of structural break for the long run relationship equation and we found that there were no structural breaks as it was seen in the model. Since the cumulative sum and the cumulative sum of squares of the residual lies in between the two critical lines, the parameters are stable.

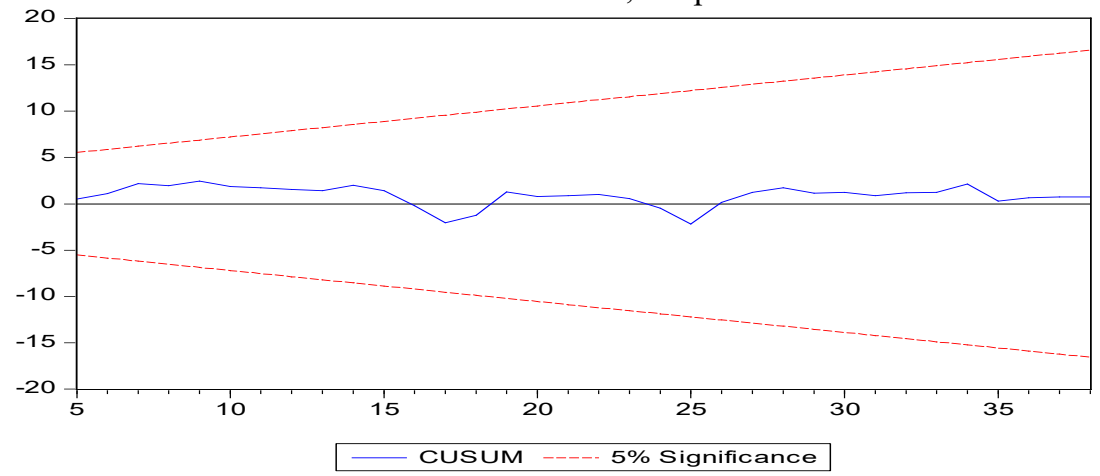

Figure 1.1 CUSUM Test 


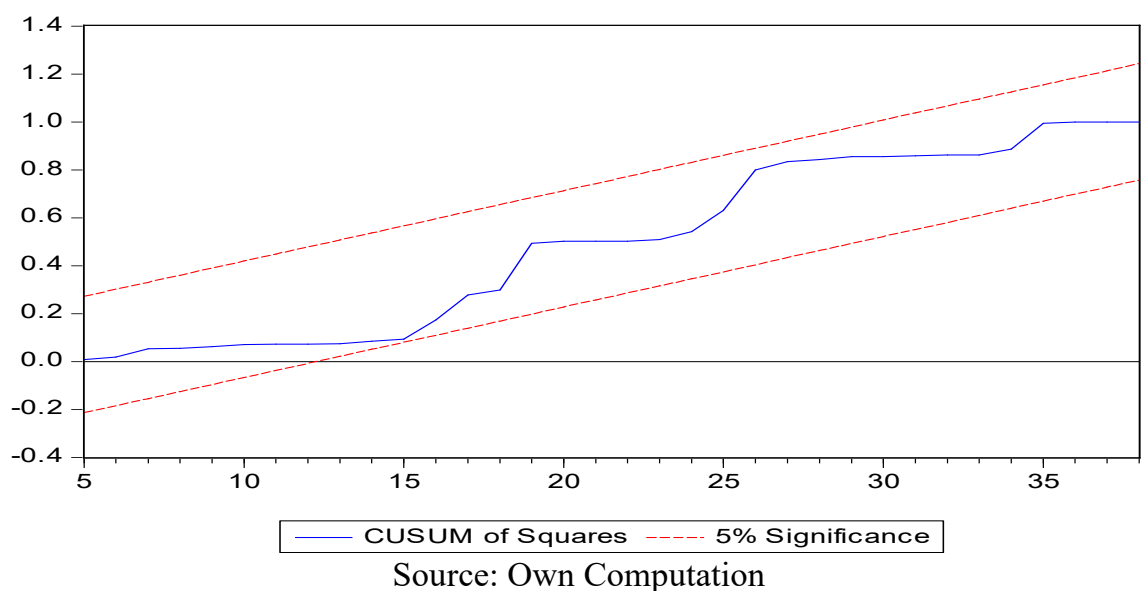

Figure 4.2 CUSUM of Squares test

\section{Conclusion and Policy Recommendation \\ 5.1 Conclusion}

In this study the empirical relationship between economic growth and remittances is investigated by including some of the explanatory variables like human capital, level of remittance inflows, gross capital formation, labor force, rate of inflation and national saving. By using the ARDL approach we have analyzed the effect of remittance inflows on economic growth for the period 1980/81-2017/2018.

The results of the econometric analysis have indicated that there is a long run relationship between economic growth and the explanatory variables. In line with the theoretical foundation Human capital proxied by secondary school enrollment is found to have a positive and significant effect on economic growth both in the short run and long run.

Labor force and gross capital formation are found to have a positive and significant impact on economy in the long run. In the short run, however due to the fact that the majority of the population are characterized by dependency and there is low saving rate in an economy the two variables have not contributed to the growth of an output.

Findings that emerge from this study also reveal that remittances have a strong and statistically significant impact on economic growth of Ethiopia. According to the findings of this paper the estimated coefficients of the level of remittance inflows has influenced the economic growth positively and significantly both in the long run and short run.

In general, as it was expected and in line with the theories from the literature review depending on the size of the economy and level of management associated with it, in addition to the traditional source of growth factors; remittances can be seen as a powerful tool in boosting the economic growth of countries like Ethiopia.

\subsection{Policy Recommendations}

Some of the policy implications of the study are jotted as follows:-

* Policies that increase the educational quality and coverage by facilitating the accumulation of human capital, making educational potential less dependent on personal and social circumstances has to be designed by government; so that the income obtained from remittance inflows can be used for human capital investment which is considered as an input for growth.

* The government has to expand opportunities for current and future workers by creating a well developed and organized financial system that are more competitive in nature and responds to the needs of the migrants. The more competitive financial system will reduce cost of remittance by diverting the remittance flows from the informal sector to the formal sector, and thus raise the volume of remittance available to various households.

* The government has to work towards pulling remittances for capital market access of financial institutions or Countries.

* Policies that enable us to monitor, analyze and give projection of remittance inflows to developing retail payment systems for remittance transfer has to be implemented by the concerned body.

\section{References}

Harris, John R., and R. H. Sabot. "'Urban Unemployment in LDCs: Towards a More General Search Model." In

Migration and theLaborMarketin Developing Countries." Journal of Political economies, 1982.

Isaacs, Leon. Scaling Up Formal Remittances To Ethiopia. paris: International Organization for Migration, 2017. 
Kagan, Julia, and Chris B Murphy. Remittance . Investopedia, 2019.

KNOMAD. Migration and Remittances:Recent Developments and Outlook. Washington, DC: World Bank Group, 2017.

Lucas, Robert E. B., and Oded Stark. "Motivations to Remit: Evidence from Botswana." Journal of Political Economy, Vol. 93, No. 5, 1985: pp. 901-918.

Nkoro, Emeka, and Aham Kelvin. "Autoregressive Distributed Lag (ARDL) cointegration technique:application and interpretation ." Journal of Statistical and Econometric Methods, vol.5, no.4, 2016: 63-91.

Pettinger, Tejvan. "Factors affecting economic growth." 2017.

Rapoport, Hillel, and Frédéric Docquier. The Economics of Migrants' Remittances ,Working Paper No. 236. Elsevier-North Holland, forthcoming, 2004.

Rasmidatta, Pinchawee. "The Relationship Between Domestic Saving and Economic Growth And Convergence Hypothesis: Case Study Of Thailand." 2011.

Rittenberg, Libby. Macroeconomics Principles (v. 2.0). 2012.

Shera, Adela, and Dietmar Meyer. "Remittances and their impact on Economic Growth." periodica polytechnica, $121,2013$.

Stark, Oded, and Davi Levhari. " "On Migration and Risk in LDCs." Econ. Development and Cultural Change." Journal of Political Economy, 1982: pp.191-196.

Appendix 1: Data set used for the study

\begin{tabular}{|c|c|c|c|c|c|c|c|}
\hline Year & $\begin{array}{l}\text { RGDP in } \\
\text { constant } \\
\text { prices }\end{array}$ & $\begin{array}{l}\text { Rem in } \\
\text { millions }\end{array}$ & RI general & $\begin{array}{l}\text { GCF in } \\
\text { millions }\end{array}$ & NS in millions & $\begin{array}{l}\mathrm{HC} \\
\text { enrollment } \\
\text { rate }\end{array}$ & $\mathrm{LF}$ \\
\hline $1980 / 81$ & 108920 & 12222222.33 & 4.482537806 & 21,880 & 17412.58417 & 281468 & 24.18 \\
\hline $1981 / 82$ & 109170 & 10483091.35 & 6.135967187 & 22,075 & 14737.96631 & 279584 & 24.87 \\
\hline $1982 / 83$ & 120202 & 10193236.35 & 5.890061077 & 21,632 & 16647.28351 & 324787 & 25.56 \\
\hline $1983 / 84$ & 111616 & 11014492.99 & -0.675378065 & 28,002 & 23275.07712 & 371306 & 26.26 \\
\hline $1984 / 85$ & 101803 & 11497584.34 & 8.417273783 & 16,067 & 12461.05211 & 426277 & 26.94 \\
\hline $1985 / 86$ & 111910 & 14202898.98 & 19.06468514 & 27,052 & 27554.20032 & 487179 & 27.6 \\
\hline $1986 / 87$ & 126611 & 13574879.65 & -9.808765071 & 29,350 & 24681.05675 & 535152 & 28.3 \\
\hline $1987 / 88$ & 125936 & 8550724.983 & -2.428672483 & 38,448 & 34257.81993 & 579834 & 29.7 \\
\hline $1988 / 89$ & 126868 & 11304347.99 & 7.080715321 & 27,202 & 27307.55563 & 602339 & 30.4 \\
\hline $1989 / 90$ & 132336 & 6473430.157 & 7.817301182 & 24,516 & 24858.49042 & 655517 & 31.09 \\
\hline 1990/91 & 128347 & 5217391.491 & 5.152481242 & 19,684 & 13565.15525 & 742351 & 32.47 \\
\hline $1991 / 92$ & 125406 & 9758454.323 & 35.72259823 & 16,754 & 16350.02593 & 842750 & 33.16 \\
\hline $1992 / 93$ & 139412 & 15019130.71 & 10.52744401 & 29,027 & 33679.14084 & 873876 & 34.55 \\
\hline $1993 / 94$ & 139480 & 18379999.16 & 3.543065962 & 31,469 & 30407.35156 & 870262 & 35.93 \\
\hline $1994 / 95$ & 147455 & 24625669.48 & 7.593876002 & 35,958 & 46877.67208 & 858846 & 36.62 \\
\hline $1995 / 96$ & 162373 & 27359669.44 & 10.02217336 & 40,856 & 49085.1973 & 775211 & 37.31 \\
\hline $1996 / 97$ & 169247 & 16012210.36 & -8.484248689 & 43,065 & 46035.0093 & 712489 & 38.69 \\
\hline $1997 / 98$ & 167917 & 9232460.373 & 2.395209581 & 42,821 & 49049.07533 & 714622 & 39.38 \\
\hline 1998/99 & 178513 & 27313236.47 & 0.894801694 & 44,834 & 30167.05192 & 747146 & 40.76 \\
\hline $1999 / 00$ & 184881 & 33729646.61 & 7.941448641 & 44,195 & 39855.89862 & 810604 & 42.15 \\
\hline $2000 / 01$ & 198595 & 53158882.38 & 0.662458109 & 50,811 & 47959.85557 & 889650 & 33.8 \\
\hline $2001 / 02$ & 201840 & 18313718.17 & -8.237844534 & 57,784 & 41706.18185 & 468169 & 34.9 \\
\hline $2002 / 03$ & 197604 & 32986894.42 & 0.675089102 & 52,050 & 43220.46633 & 1056379 & 36.2 \\
\hline $2003 / 04$ & 220782 & 46470192.46 & 13.6740452 & 70,593 & 62543.31193 & 1186963 & 37.04 \\
\hline $2004 / 05$ & 248698 & 133742806.2 & 3.327370479 & 70,719 & 65640.23512 & 1486806 & 38.4 \\
\hline $2005 / 06$ & 277396 & 173519405.7 & 9.969971235 & 83,153 & 66921.50929 & 1695955 & 39.6 \\
\hline $2006 / 07$ & 310115 & 172153314 & 12.29947631 & 81,346 & 92239.25619 & 1785655 & 40.7 \\
\hline $2007 / 08$ & 344775 & 357838225 & 17.24040083 & 91,086 & 86462.00072 & 2053593 & 40.6 \\
\hline 2008/09 & 379362 & 386696265.8 & 44.35668588 & 100,693 & 93151.82217 & 2382129 & 39.3 \\
\hline $2009 / 10$ & 419218 & 261601951.5 & 8.483644045 & 123,118 & 112981.7338 & 2869032 & 41.4 \\
\hline $2010 / 11$ & 475648 & 345150775.5 & 8.14926403 & 165,380 & 161984 & 3238978 & 42.82 \\
\hline
\end{tabular}




\begin{tabular}{|l|l|l|l|c|c|l|l|}
\hline Year & $\begin{array}{l}\text { RGDP in } \\
\text { constant } \\
\text { prices }\end{array}$ & $\begin{array}{l}\text { Rem in } \\
\text { millions }\end{array}$ & RI general & $\begin{array}{l}\text { GCF in } \\
\text { millions }\end{array}$ & NS in millions & $\begin{array}{l}\text { HC } \\
\text { enrollment } \\
\text { rate }\end{array}$ & LF \\
\hline $2011 / 12$ & 517027 & 513238171 & 33.24995988 & 207,608 & 171434.3208 & 3467133 & 44.26 \\
\hline $2012 / 13$ & 568432 & 937525801.9 & 24.12435395 & 210,908 & 174030.5642 & 3574877 & 45.7 \\
\hline $2013 / 14$ & 626977 & 833031317 & 8.079723678 & 259,173 & 206586.6859 & 3853280 & 47.3 \\
\hline $2014 / 15$ & 692222 & 1796377787 & 7.402193468 & 296,901 & 236702.2226 & 4170276 & 48.8 \\
\hline $2015 / 16$ & 1449397 & 1086986751 & 10.11074774 & 585,665 & 502076 & 4535121 & 50.4 \\
\hline $2016 / 17$ & 1595316 & 772235946.6 & 7.263731539 & 659,734 & 518403.5581 & 4011778 & 52 \\
\hline $2017 / 18$ & 1717795 & 392986446.2 & 9.848250242 & 625,313 & 590222.1298 & 4273449.5 & 69.5 \\
\hline
\end{tabular}

